\title{
Challenges to Farmers' Participation In Artificial Insemination (AI) Biotechnology In Nigeria: An Overview
}

\author{
Shehu B.M. ${ }^{1}$, Rekwot P.I. ${ }^{2}$, Kezi D.M. ${ }^{1}$, Bidoli, T.D. ${ }^{1}$ and Oyedokun, A.O ${ }^{1}$ \\ ${ }^{1}$ National Agricultural Extension and Research Liaison Service, \\ PMB 1067, Ahmadu Bello University, Zaria \\ Email: balashehu2000@yahoo.com; balashehu@naerls.gov.ng \\ Mobile: 08050878016 \\ ${ }^{2}$ National Animal Production Research Institute, \\ Ahmadu Bello University, Zaria
}

\begin{abstract}
Livestock farming is an important source of animal based food products and income in Nigeria. To improve livestock production in the country, technologies such as artificial insemination have to be understood and transferred properly by Livestock Extension Agents (LEA) to farmers for proper adoption. This technology has been applied for some years in a number of countries using the appropriate extension approaches. Advantages claimed for the practice are the lessening of the risk of spread of disease in livestock, reduction in sterility and increase in fertility, facilitation of improvement in quality, and economy in livestock management. Against this background this paper highlights the benefits of Al technology, factors limiting against Al program in Nigeria, suggest the appropriate extension methods for disseminating the technology and suggest strategies that should be put in place to make Al technology sustainable in livestock production for increased productivity.
\end{abstract}

Keywords: artificial insemination (Al), technology, livestock, Nigeria.

\section{INTRODUCTION}

Artificial insemination (Al) is a process by which sperm are collected from male, processed, stored, and artificially introduced into the female reproductive tract for the purpose of conception. Al was the first great biotechnology applied to improve reproduction and genetics of farm animals and it has also had an enormous impact worldwide in many species, particularly in dairy cattle (Foote, 2002). The early history of Al dates back to 1677 when Leeuwenhoek discovered spermatozoa but progress rested in anticipation of the first successful bitch insemination by Spallanzani in 1780 (Foote, 1999). Further milestones in the development of Al technology are detailed in Table 1. Since 1780 the principle of artificial insemination has not changed much, however there has been improvement in the use of this technology for specific production purposes. In the 
case of cattle, artificial insemination has developed the dairy industry into what it is today.

TABLE 1: Milestone events in the development of Al technology

\begin{tabular}{|c|c|c|}
\hline Year & Event & Researcher(s) \\
\hline 1677 & $\begin{array}{l}\text { Discovery of sperm by the use of a } \\
\text { magnifying lens }\end{array}$ & Anton van Leeuwenhoek \\
\hline 1780 & $\begin{array}{l}\text { Artificial insemination of a dog bitch and } \\
\text { the subsequent birth of pups } 62 \text { days } \\
\text { later }\end{array}$ & Spallanzani \\
\hline 1803 & $\begin{array}{l}\text { Freezing of stallion sperm in the snow } \\
\text { and motility recovered after warming }\end{array}$ & Spallanzani \\
\hline 1890 & Al in horses first attempted in France & Repiquet \\
\hline 1899 & $\begin{array}{l}\text { Started work on horse Al at Moscow } \\
\text { State University }\end{array}$ & Ivanov \\
\hline 1912 & $\begin{array}{l}\text { Demonstrated Al in horses, achieved } \\
\text { results comparable to those obtained by } \\
\text { natural service. Achieved success in } \\
\text { cattle and sheep Al and trained hundreds } \\
\text { of inseminators }\end{array}$ & Ivanov \\
\hline 1914 & $\begin{array}{l}\text { Start of work in Italy which led to artificial } \\
\text { vagina for semen } \\
\text { collection in the dog }\end{array}$ & Amantea \\
\hline $\begin{array}{l}\text { 1920s } \\
\text { and1930s }\end{array}$ & $\begin{array}{l}\text { Development in Russia of artificial } \\
\text { vaginas for use in bulls, stallions and } \\
\text { rams; development of simple diluents }\end{array}$ & Milavanov \\
\hline 1936 & $\begin{array}{l}\text { Shipment of ram semen from Cambridge } \\
\text { in the UK to Poland; birth of lamb after Al }\end{array}$ & Arthur Walton \\
\hline 1937 & $\begin{array}{l}\text { Development in Denmark of the } \\
\text { rectovaginal method of } \mathrm{Al} \text { in cattle }\end{array}$ & Various Danish workers \\
\hline 1941 & $\begin{array}{l}\text { Development of egg-yolk citrate semen } \\
\text { diluents for cattle }\end{array}$ & Glenn Salisbury \\
\hline 1946 & $\begin{array}{l}\text { Antibiotics (penicillin and streptomycin) } \\
\text { used to control pathogenic } \\
\text { microorganisms in semen used for Al }\end{array}$ & Almquist \\
\hline 1949 & $\begin{array}{l}\text { Method of freezing sperm of several } \\
\text { species discovered }\end{array}$ & Chris Polge \\
\hline 1952 & $\begin{array}{l}\text { First calf born (Frosty I) after use of } \\
\text { frozen-thawed bull semen in Cambridge }\end{array}$ & $\begin{array}{l}\text { Chris Polge and } \\
\text { Tim Rowson }\end{array}$ \\
\hline 1960 & $\begin{array}{l}\text { Liquid nitrogen became the refrigerant of } \\
\text { choice for preserving bull semen. Most } \\
\text { countries used } 100 \% \text { frozen bull semen }\end{array}$ & $\begin{array}{l}\text { Many researchers in } \\
\text { various countries }\end{array}$ \\
\hline
\end{tabular}

Source: Gordon I.R. (2004). Reproductive Technologies in Farm Animals 
The first cattle Al cooperative was started in the United States in New Jersey in 1938 (Foote, 1999). The development of techniques for frozen livestock and wild animals' semen across the globe has made Al practice a reality (Nishikawa, 1964). However, in developing countries like Nigeria, improvements in livestock production have generally been lacking, and one of the principal limiting factors has been the lack of genetically improved animals. There are different ways of increasing the numbers of genetically improved animals. Selection within existing local populations may be practised, but this method often has to be ruled out because of the low genetic base with which one has to start. The importation of superior breeding stock is too costly to be adopted on a large scale. Problems of adaptability also arise when high-yielding cattle are transferred from temperate to tropical and subtropical environments. Crossing local females with superior imported sires is another method adopted at different periods by many developing countries. With the advent of Al, the principle of crossbreeding which is to reproduce genetically improved animals was given a new instrument for implementation on a large scale and at comparatively low cost.

In view of the above, this paper highlights the benefits of Al technology, factors limiting against Al program in Nigeria, suggest the appropriate extension methods for disseminating the technology and suggest strategies that should be put in place to make Al technology sustainable in livestock production for increased productivity.

\section{Artificial insemination practice in Nigeria}

The first documented artificial insemination in cattle in Nigeria was carried out at the Livestock Improvement Centre Vom, Plateau State in August 1949 using imported bull semen. Other reports on artificial insemination in the country could be found in annual report of Livestock Investigation Centre, Vom. The report indicated that thirteen Friesian $\mathrm{x}$ Zebu calves were born following artificial insemination (Annual Report, DVR, 1952-53). Artificial insemination was practiced routinely at the Agege Dairy Farm; Lagos State in the sixties and early 70's where Friesian cows were maintained. Artificial insemination was also practiced on a small scale and for a short time at Iwo Road Dairy, Ibadan, Oyo State; Fashola Stock Farm near Oyo; and University of Ibadan Teaching and Research Farm (Osinowo, 1980).

The main reasons why artificial insemination were practiced by these farms were to control diseases in the Government and Institutional farms as well as produce cross-bred animals for distribution to other Livestock Investigation and Breeding Centres (LIBCs) and to a few interested local individuals. This continued until 1976 when the Decree promulgating National Animal Production Research Institute (NAPRI) Shika, Zaria was enacted (Bale, 2003). Artificial insemination Unit was established as a service Unit at the National Animal Production Research Institute (NAPRI) under the auspices of Ahmadu Bello University (A.B.U), Zaria, and it received a Federal Government mandate to (a) service the states artificial insemination programmes, (b) train inseminators, (c) collect and distribute semen from genetically promising bulls, (d) import semen from overseas and distribute to the states and (e) serve as a record centre for artificial insemination activities, ( $f$ ) 
be responsible for the introduction and extension of artificial insemination services in the States and Federation.

The first documented insemination was carried out by Artificial Insemination Unit of NAPRI on the 16th January 1978 using locally processed chilled semen collected from a Sokoto Gudali bull three days prior to insemination (Voh, 1990). Bull semen for artificial insemination was also imported from Britain, Holland, U.S.A and Sweden (Bale, 2003). Rotary Club International, Zaria, International Bull Semen Donation Scheme of FAO and International Atomic Energy Agency (IAEA) also made semen donations. Apart from artificial insemination in cattle, extensive work has also been done on sheep using artificial insemination techniques in NAPRI. Some researchers at Ibadan and Nsukka Universities had worked on semen preservation using different extenders and preservatives to store semen of boars, rams, bucks and poultry (Osinowo et al., 1980; Azubuike and Orji, 1983; Ahmed, 1989; Butswat, 1989).

The advantages of artificial insemination technology

1. Crossbreeding: It allows the opportunity to mix imported breeds with local cattle breeds to create cattle that are better than their parent local breeds and is one of the most effective low-input, high-output management practices that a farmer can adopt.

2. Decreased costs: Male animals often grow to be larger than females and can consume relatively larger amounts of feed. Also, male animals are often more strong, powerful, and potentially ill-mannered and thus require special housing and handling equipment.

3. Reduced disease transmission: Natural mating allows for the transfer of venereal diseases between males and females. Some pathogens can be transmitted in semen through artificial insemination, but the collection process allows for the screening of disease agents. Collected semen is also routinely checked for quality, which can help avoid problems associated with male infertility

4. Increased potential for genetic selection: Because artificial insemination allows males to produce more offspring, fewer males are needed. Therefore, one can choose only the few best males for use as parents, increasing the selection intensity.

5. Increased efficiency of bull usage: During natural breeding, a male will deposit much more semen than is theoretically needed to produce a pregnancy. In addition, natural breeding is physically stressful. Both of these factors limit the number of natural mating a male can make. However, collected semen can be diluted and extended to create hundreds of doses from a single ejaculate. Also, semen can be easily transported, allowing multiple females in different geographical locations to be inseminated simultaneously, and semen can be stored for long periods of time, meaning that males can produce offspring long after their natural reproductive lives end 
6. Increased safety for animals and farmers: As mentioned, male animals can become large and aggressive. These factors mean that maintaining a bull on a farm may be dangerous. Also, because of the relatively larger size of adult males than females, natural mating is more likely to result in accidents and injury to either the cow or the bull than is artificial insemination.

\section{Disadvantages of artificial insemination technology}

There are a few disadvantages of $\mathrm{Al}$ which can be overcome through proper management.

1. Proper implementation requires special training, skill and practice.

2. It requires more labour, facilities and managerial skill than natural service.

3. Preservation and transportation of semen is difficult under severe climatic conditions like those prevailing in most parts of Nigeria.

\section{Challenges to farmers' participation in Al biotechnology in Nigeria}

Some of the challenges that are inimical to the adaptation and utilization of the technology include:

a) Low base of genetically improved animals.

b) Difficulties of obtaining the necessary equipment, laboratory supplies and skilful personnel.

c) Type of animal husbandry practice among the nomadic and the seminomadic Fulani. The nomads move from place to place in search of feed and water throughout the whole year and more especially during the dry season.

d) Lack of education with respect to usefulness of artificial insemination has contributed to the slow development of artificial insemination practices.

e) Inadequate attention being given to the development of livestock industry compared to crops (arable and cash).

f) Lack of incentive to artificial insemination workers in terms of transport and overtime.

g) Frequent breakdown of liquid nitrogen plant because of power failure or non availability of liquid nitrogen.

h) Improper heat detection and lack of adequate record by private cattle owners.

\section{CONCLUSION}

To improve livestock production, the government should make Al accessible; educate farmers on breeding through extension education to enhance their appreciation of $\mathrm{Al}$; encourage record keeping and help improve livestock product marketing, disease control and communication infrastructure. Mwangi et al (2004) reported that there is a direct relationship between extension education coverage and $\mathrm{Al}$ utilization implying that extension coverage has a direct bearing on $\mathrm{Al}$ awareness and usage levels. Chitere (1985) also found that extension education positively influenced technology adoption and utilization. The more educated on 
the importance of Al the farmers are, the more likely they are to use it if there were no other limiting factors. Unavailability of a technology can severely constrain its adoption and use (World Bank, 1992).

\section{RECOMMENDATIONS}

Although, serious government intervention is required to bring about the fast tracking of animal agriculture in general, the following are a few suggestions for better Al technology adaptation and utilization:

1. Establishment of semen collection from improved breeds and storage centres across the country. These centres should also have facilities for training inseminators to facilitate transfer of technology (TOT).

2. Farmers should be educated through extension service systems on the benefits of Al to enhance their appreciation of Al.

3. Focus should be on farmers practicing intensive management systems to start with and not nomadic farmers. Nomadic farmers are always on the move; as a result they cannot be closely monitored.

4. Do-it-yourself insemination (DIY-AI) should be encouraged as farmers can be trained to carry out inseminations themselves on their farms after attending an approved training course. However, it is recommended that farmers using DIY-Al should undertake a refresher course at least every second year.

5. Privatization of Al services should be encouraged. The efficiency of $\mathrm{Al}$ technicians will improve as Al services become privatized and competition for inseminators to market their skills will increase.

6. Government should reduce or remove tariffs on livestock equipment and other inputs.

\section{REFERENCES}

Ahmed, M.S. 1989. Comparative evaluation of cryoprotective compounds for deep freezing of ram spermatozoa in tries dilute. Ph.D Thesis,Ahmadu Bello University, Zaria, Nigeria.

Annual Report of the Federal Department of Veterinary Research, Nigeria. 19521955, pp. 8.

Azubuike, M. E. and Orji, B.I. 1983. Palm wine as a dilute for porcine semen. Abstract, Nigerian Society for the Study of Reproduction. $3^{\text {rd }}$ Annual Meeting, University of Ife, lle-Ife.

Bale, J.O.O. 2003. Artificial insemination practice in Nigeria- review of the dangers of disease transmission. Nigerian Journal of Animal Production, 30(1): 117-126

Butswat, I.S. 1989. Ram semen preservation at ambient temperatures by flow dialysis techniques. M.Sc Thesis, Ahmadu Bello University, Zaria. 
Chitere, P.A (1985). Extension education and farmers performance in improved crop farming in Kakamega District (Kenya). Agricultural administration 18: 39-57

Foote, R. H. 1999. Artificial insemination from the origins up to today. In: Proceedings of the International Symposium. From the first artificial insemination to the modern reproduction biotechnologies: traditional ways and the new frontiers of animal production. Reggio Emilia (Italy), 23-68

Foote, R. H. 2002. The history of artificial insemination: Selected notes and notables. American Society of Animal Science.

Gordon, I.R. 2004. Reproductive technologies in farm animals. CAB International, Wallingford, UK. pp. 49.

Mwangi, J.G.,Ronoh,T.W and Asiabaka,C.C. 2004. Factors related to the use of Artificial Insemination by subsistence dairy farmers in Bomet district, Kenya. International Journal Agricultural Rural Development 5: 164-175.

Nishikawa, Y. 1964. History and development of artificial insemination in the world. Proceedings of the $5^{\text {th }}$ International Congress Animal Reproduction. Trento, 7: 162.

Osinowo, O. A., Bale, J. O., Eduvie, L.O. and Oyedipe, E.O 1980. Characteristics of ram semen and development of new techniques. Annual Report of Research in Animal Production. 23.

Osinowo, O.A. 1980. A practical Al scheme for Nigeria. NAPRI Seminar Series 2: $1-15$.

Voh, A.A. Jrn. 1990. A decade of practical artificial insemination extension services at the National Animal Production Research Institute, Shika (19791989). In: Application of Animal Reproduction and Artificial Insemination Techniques to Livestock Production in Nigeria 260-272. 